
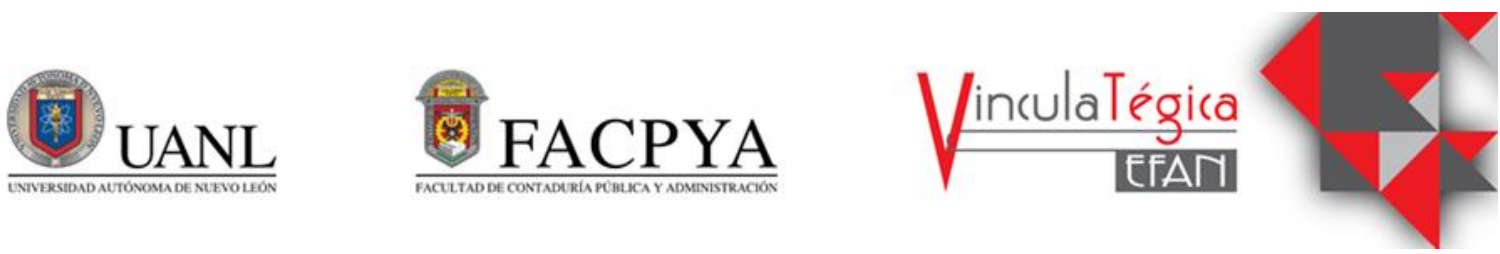

\title{
ESG impact on financial corporate performance and portfolio returns: evidence of Australia and Japan
}

\author{
Margarita Chrissanthi Kazakakou Powaski ${ }^{1}$; Carolina Daza Ordoñez ${ }^{2}$ \\ y Laura Jáuregui Sánchez ${ }^{3}$ \\ 1Universidad de Monterrey, margarita.kazakakou@udem.edu, \\ Av. Ignacio Morones Prieto 4500-Pte., Zona Valle Poniente 66238, San Pedro Garza García, N.L., 81-82151488 (+44) \\ 8112720589 \\ 2Universidad de Monterrey, carolina.daza@udem.edu, \\ Av. Ignacio Morones Prieto 4500-Pte., Zona Valle Poniente 66238, San Pedro Garza García, N.L., 81-82151258 (+44) \\ 8112556148 \\ 3Universidad de Monterrey, laura.jauregui@udem.edu, \\ Av. Ignacio Morones Prieto 4500-Pte., Zona Valle Poniente 66238, San Pedro Garza García, N.L., 81-82151488 (+44) \\ 8112115354
}

Información del artículo revisado por pares

Fecha de aceptación: junio-2021

Fecha de publicación en línea: octubre-2021

DOI: https://doi.org/10.29105/vtga7.2-5

\begin{abstract}
Environmental, Social, and Governance investing has undergone a radical shift; companies and investors have focused on the impact of the disclosure of the practices and policies related to the environment, social responsibility, and governance in their operational strategies and investment. The purpose of this paper is to demonstrate the impact that the ESG policies have on public companies' stock returns in Australia and Japan. Accounting and market-based measures are used to determine the impact ESG practices have on stock market index returns. The annual data used is of companies from Australia's S\&P/ASX Index and Japan's Nikkei 225 Index, covering the period from 2005 to 2019. Fixed effect model regression was used to test the significant relationship between companies' stock returns and ESG score, accounting, and market-based measures. Portfolios were created to analyze the risk/return relationship between companies with and without ESG across countries. The findings indicate mixed results. Australia's non-ESG portfolios
\end{abstract}

\section{Resumen}

La inversión ambiental, social y de gobernanza ha experimentado un cambio radical; empresas e inversionistas se han centrado en el impacto de la divulgación de las prácticas y políticas relacionadas con el medio ambiente, la responsabilidad social y la gobernanza en sus estrategias operativas e inversiones. El propósito de este documento es demostrar el impacto que las políticas ESG tienen en la rentabilidad de las acciones de las empresas públicas en Australia y Japón. Se utilizan medidas contables y de mercado para determinar el impacto que tienen las prácticas ESG en los rendimientos de los índices bursátiles. Los datos anuales utilizados son de empresas del índice $\mathrm{S} \& \mathrm{P} / \mathrm{ASX}$ de Australia y del índice Nikkei 225 de Japón, que cubren el período de 2005 a 2019. Se utilizó la regresión del modelo de efectos fijos para probar la relación significativa entre la rentabilidad de las acciones de las empresas y la puntuación ESG, la contabilidad y medidas basadas en el mercado. Se crearon carteras para analizar la relación riesgo/rentabilidad entre empresas con 
outperform the S\&P500 and ESG portfolios. Japan's portfolio has positive returns but underperforms the benchmark. Low market capitalization portfolios with and without ESG outperform the higher capitalization portfolios.

Keywords: $E S G$, fixed-effects model regression, portfolio, sharpe ratio, Jensen alpha.

JEL: G11, G15, G19. y sin ESG en todos los países. Los hallazgos indican resultados mixtos. Las carteras no ESG de Australia superan a las carteras S y P500 y ESG. La cartera de Japón tiene rendimientos positivos, pero está por debajo del índice de referencia. Las carteras de baja capitalización de mercado con y sin ESG superan a las carteras de mayor capitalización.

Palabras clave: ESG, modelo de efectos fijos, portafolio, sharpe, Jensen alpha.

\section{INTRODUCTION}

Over the last years, an increasing number of investors search for better long-term financial value rather than shareholder profit maximization as it has been for the last century. Nowadays, investors demand trust, transparency, ethics, respect for the environment, and greater social responsibility (Boffo \& Patalano, 2020). Hence the incorporation of Environmental, Social, and Governance (ESG) factors in evaluating firm corporate performance, profitability, and returns in the investment decisionmaking process.

To satisfy the investors' need for information, given the environmental and social risk factors that have arisen over time, various metrics methodologies (qualitative and quantitative) are developed by different firms that provide a company assessment and an ESG disclosure score (Boffo \& Patalano, 2020).

ESG refers to the central factors for measuring a company's environmental, social responsibility, and governance impact. The ESG score is a metric composed of three fundamental elements: Environmental Disclosure Score (EDS), Social Disclosure Score (SDS), and Governance Disclosure Score (GDS). The environmental factor is how a company's behavior affects the environment, which entails resources, innovation, and carbon emissions. The

social factor is the behavior of a company and its relationship to social issues, which involves the safety of their production and products, satisfaction or exploitation of their workers, and human rights. Finally, the governance factor is how the company operates internally, which entails transparency and anticorruption, employee and executives' compensation, and the board of directors' composition, among others (MSCI, 2020).

The ESG ecosystem includes organizations for governing principles (World Economic Forum, Principles for Responsible Investment-PRI, OECD and $\mathrm{UN}$ ), reporting frameworks (SASBI, ISO), rating agencies (Sustainalytics, S\&P global, Refinitiv, MSCI), educational resources (Nossa Capital, CFA Institute, GIIN), assurers (KPMG, EY, Deloitte, PwC, Bureau Veritas) and data providers (Thomson Reuters, MSCI, Bloomberg, S\&P, FTSE Russell).

The European Federation of Financial Analysts Societies (DVFA \& EFFAS, 2009) and the Society of Investment Professionals in Germany (DCFA) published a report that includes the fundamental 30 Key Performance Indicators (KPI) for ESG reporting per sector. Those indicators are raw ESG data that can be benchmarkable per sector.

Data providers intend to supply trustworthy information that measures the company's environmental, social, and governance practices and assign a 
disclosure score (Escrig-Olmedo et al., 2019). The disclosure score obtained by assigning quantitative and qualitative values to the company's effectiveness and efficiency in sustainability, long-term growth, prosperity, transparency, and governance matters, allows investors to count on an objective comparison parameter for the decision making.

Currently, there is a growing interest and importance in the ESG term. Companies and investors are increasingly applying these non-financial factors as part of their analysis process. Firms have realized that having policies related to environmental, social responsibility, and governance and disclosing them to the public can significantly impact their market value.

Investors have identified material risks and growth opportunities on companies that applied ESG policies. Currently, investment valuation has evolved from a financial to a strategic matter (Standard \& Poor's, 2004). Analysis of factors that include social responsibility practices, covering topics regarding environmental, social, and governance matters (ESG), such as climate change, directors' retributions, diversity, inclusion, and tax transparency are of great importance (MSCI, 2018).

According to the (CFA Institute, 2018), companies that apply ESG factors in their practices become more attractive to investors who incorporate these factors into their investment process. Fundamental analysis also improves with the inclusion of ESG factors.

Despite this, the integration of ESG in an overall strategy remains a challenge (Ambec \& Lanoie, 2007). Hence, there is a lack of investigation into the impact of the ESG and companies' financial performance.

The objective of the study is twofold. First, determine which market and accounting-based factors affect companies' returns with and without ESG scores for public companies in Australia and Japan based on S\&P/ASX and Nikkei 225 samples. Second, determine if the risk-return performance of ESG portfolios from the same countries outperforms portfolios that are not ESG based.

The Responsible Investment Association Australasia (RIAA), the largest network of companies and organizations engaged in ESG investing across Australia and New Zealand, in their 2020 annual report, has 307 members managing $\$ 9$ trillion assets globally. RIAA members include "super funds, fund managers, banks, consultants, researchers, brokers, impact investors, property managers, trusts, foundations, faith-based groups, financial advisers and individuals" (RIAA Annual Report 2020 Financial Year, 2020).

MSCI ESG and Bloomberg ESG metrics deliver a broad set of standardized ESG data and simple comparable metrics (MSCI, 2020). Risk exposure involves macro risk factors such as carbon regulation, water-stressed regions, and corruption risk. Carbon regulation risk involves three factors: 1) each country's annual emissions reduction implied by its stated targets, 2) contingency of country targets on external support, and 3) the required emissions reduction implied by the country's share of the remaining global carbon budget. Water-stressed regions involve climate change and rising demand for water supply availability. Furthermore, the FMI estimates that the bribery costs in the global economy are as much as 1.5 trillion dollars per year, and accusations of corruption remain increasing in global companies. 
Table 1. MSCI ESG Metrics: Geographic ESG risk exposure.

\begin{tabular}{lll}
\hline & Australia & Japan \\
\hline Carbon regulation & High Risk & High Risk \\
Water stressed regions & High Risk & Medium Risk \\
Corruption & Low Risk & Low Risk \\
\hline
\end{tabular}

MSCI (2021).

\begin{abstract}
The Japan Sustainable Investment Forum reports that sustainable investment in Japan reached 3.1trillion USD in 2019, representing almost $60 \%$ of professionally managed money in Japan. Japanese ESG investments are $38,55 \%$ in Bonds, $33.72 \%$ in Japanese equity, $21.5 \%$ in foreign equity, and $6 \%$ in other types of investment (JSIF, 2020).

The structure of the remainder of the study is as follows: section 2 literature review, section 3 the data description and methodology, section 4 the empirical results, and lastly, the conclusions.
\end{abstract}

\section{LITERATURE REVIEW}

\section{ESG and firm performance}

In the 1980s, organizations and companies started considering environmental, social responsibility, and governance issues in company performance. In 2005 the International Financial Corporation introduced the official term of ESG (UN Global Compact et al., 2005). The term is currently widely accepted in the financial sector in general. Nowadays, academics and practitioners' study to validate the impact of the ESG qualitative factors on the financial performance of companies (Fink, 2020).

In the early years, the social factor was the most relevant parameter taken into consideration. Later, the governance factor was considered together with the social variable for research. After the reshaping of the financial market in 2005, the environmental factor became relevant in academic investigations.

A study carried on by PWC indicates that $74 \%$ of the CEOs interviewed assures that they measure and disclose the impact of their companies' total activities, regarding social, environmental, tax, and economic dimension comes into play in their long term success (Nally \& Grygler-Siddons, 2014). This measurement and disclosure generate the ESG index, which includes information that the companies voluntarily decide to disclose. Investors are increasingly relying on making their investment decisions. With the new information needs demanded by investors, at the end of the last century, the first important findings began to emerge in the literature on the importance of disclosing financial and voluntary non-financial information, such as ESGrelated information.

Chow \& Wong-Boren (1987) evidence a significant relationship between the firm's size and the voluntary disclosure of information. In 2002, Standard \& Poor's, made a study about transparency disclosure practices of 300 public companies along 30 countries, concluding that the non-financial information disclosed needs attention and improvement processes (Patel \& Dallas, 2005). This study also establishes the effects that information disclosure has on the performance of companies, establishing that the lesser the disclosure, the greater the market risk and, therefore, the higher the cost of capital.

Given the asymmetry of information presented by the markets, companies must have an impartial communication protocol that maintains a solid relationship between the company and its investors and shareholders (Tai \& Kuo, 2010). The transparency of such information is affected by the structure and composition of its board of directors. 
By reducing information asymmetry by disclosing financial and social information, companies reduce the cost of capital (Cuadrado-Ballesteros et al., 2016).

Cochran \& Wood (2014) reviewed the best interest of its long-term shareholders by considering new measures in companies' systems and processes. They noticed that the company reflects control in their responsibilities when implementing these processes, which generate long-term shareholder value. The authors reevaluate the relationship between corporate social responsibility and financial performance. They used as a sample a controlled group of companies in the United States. They deduced a positive relationship between the share price of public companies and the implementation of social responsibility.

Ullmann (1985) exhibits a lack of a clear trend in the relationship between market performance and the application of social responsibility policies. The research considers a sample of public companies in the United States. The results indicated that SDS (social disclosure score) was not as significant as other companies' performance variables.

Pava \& Krausz (1996) disqualifies the Ulmann approach and differs from the reported results. The authors argue that companies have a responsibility beyond normative standards, which shows a clear trend between returns and corporate responsibility.

The traditional view of financial theory changed considerably. Investors have other priorities within their investment portfolio rather than exclusively interested in obtaining a high return level for the risk assumed. This idea supports the authors' results proving that investors are willing to pay a premium for firms that implement socially responsible behavior (Pava \& Krausz, 1996).
With the increasing research interest in the impact of firms' social and governance activities, the ESG value drivers were brought together for investment analysis, processes, and decision-making in 2005. The International Finance Corporation (2005) shares the perspective of how ESG factors impact companies' performance. However, there is no definite answer of whether the impact is positive or negative.

Brammer et al. (2006) crosssectional regression model analyzed the FTSE 451 companies from 2002 to 2005. Their research supported a negative correlation between social responsibility and equity returns in the UK. The authors proposed for further investigation to examine the different aspects of each of the companies separately.

An analysis made for American companies from 2000 to 2005 concluded that investors acknowledge corporations' efforts in enforcing environmental policies. Also, corporations' benefit from regulatory costs, differentiation, and an increase in market access (Ambec \& Lanoie, 2007).

Chelawat \& Trivedi (2016) explored the relationship in the context of India. The authors conducted a study covering 93 companies from the National Stock Exchange benchmark index from 2008 to 2013. The study focused on the three components of the ESG. The regression model results for the three components of the ESG showed a positive relationship between the financial performance and the ESG policies in the long term. The authors' suggestion to include account-based factors as variables (ROA, RONW, and $\mathrm{ROE}$ ) is accepted and applied in the regression model of this study.

Following the same methodology for a study on the impact of ESG factors on Malaysian public limited companies' firm performance showed similar results. Account and marketbased variables (ROA, ROE, and share 
price) are used in the regression model. The results indicated no significant relationship between individual and combined factors of ESG and firm performance (Atan et al., 2018).

Dalal \& Thaker (2019) study the Indian market with ESG policy implementation. The primary outcome is that companies with ESG implementation produce better financial results than others that do not implement corporate social responsibility. The higher the ESG score, the better the results. For the Indian market, there is a positive relationship between ESG levels and firm value, implying that better transparency, accountability, and stakeholder trust are significant in enhancing firm performance.

Ionescu et al. (2019) study the tourism sector on an international level. The results show a positive relationship between ESG and its market value; investors integrate extra-financial performance in their investment decisions.

Results have been mixed, with various studies finding no significant difference between companies that apply ESG policies and companies that do not apply these standards. There has not been a consistent result on a positive impact of the ESG and companies' share price and performance. We aim to investigate the impact of ESG on market returns for companies in Australia and Japan.

\section{Portfolios based on ESG}

For many years the traditional investors did not accept the incorporation of ESG analysis as a criterion for their portfolio selection for fear of failing the doctrine of "Maximizing Shareholder Value" (MVS) (Clarke \& Friedman, 2016) (Amir \& Serafeim, 2018).

MVS companies in the past applied risk management when they expected financial distress in the future. Nowadays, firms are proactive and apply corporate social responsibility to mitigate risk and lower bankruptcy probabilities (Lin \& Dong, 2018).
With the creation of the ESG in 2005, academics had conducted studies with inconclusive results on the relationship between ESG portfolio management and a portfolio's risk/return profile. The portfolio returns vary due to portfolio construction costs and degree of diversification. Opponents of ESG portfolio investment align with Markowitz's portfolio diversification and believe that ESG causes a shift in the efficient frontier and does not provide all available options that an all-inclusive investable universe offers (Le Maux \& Le Saout, 2004).

There is a cost associated with upholding ESG values. This cost has two layers: the first is related to the firm and the second to the stock. The first layer indicates that implementing environmentally friendly processes and maintaining social standards (warning disclosures, product recall, etc.) is an explicit high corporate expense. The second layer is the limited investable universe. When sin stocks are removed from the pool of stocks to include in a portfolio, the mean-variance framework will not be optimal, and stocks that might provide higher returns are not included (Fabozzi et al., 2008).

However, there is a shift in people's sentiment in the last decade, and companies are held accountable for financial, environmental, and social aspects (Liagkouras et al., 2020). The Global Sustainable Investment Review (GSIA, 2019) shows continued growth for sustainable and responsible investing in developed economies, with Japan showing robust growth. Sustainable investing is the inclusion of ESG factors in portfolio selection. Europe, U.S., Canada, Japan, and Australia-New Zealand reached 30.7 trillion USD in investable assets.

Professionally managed assets in Japan were $18 \%$ (grew from $3 \%$ in 2016) and $63 \%$ in Australia. Japan and Australia are the two fastest-growing regions in sustainable investing. In 2018 
the total assets under management (AuM) had reached 75 trillion USD. In the US, one of every four dollars is invested by funds that use socially responsible investing (Serafeim \& Grewal, 2019).

Nowadays, society expects companies to be socially responsible, contribute to ethical behavior, and protect the environment. Companies that fail to do so are punished by investors and consumers (Liagkouras et al., 2020). Although the ESG disclosure is voluntary, companies face increased pressure to divulge their ESG information publicly. The United Nations Principles for Responsible Investment urges companies to apply ESG principles and align investors with society's objectives (UN PRI, 2017).

The world's leading proponent of responsible investment known as PRI understands the investment implications of the ESG factor and supports its international network of investors signatories in incorporating these factors into their investment and ownership decisions. The (UN PRI, 2017); encourages investors to use responsible investment to enhance returns and manage risk. The UN PRI is an NGO with no governmental association. Its mission is to engage with global policymakers to support and implement ESG factors.

According to the Principles for Responsible Investment Report, released in 2006, 60 countries and more than 2,000 members are currently participating. Specifically, for Australia and Japan, Australia has eight investment funds, while Japan has 9.

Even though we see an increase in Socially Responsible Investment (SRI), a meta-analysis of 85 studies does not provide conclusive evidence on the better financial performance of ESG portfolios compared to conventional investments. The main argument is that researchers use data from different sources and rating agencies. Managers face increased costs in applying ESG policies, affecting the bottom line (Revelli \& Viviani, 2015).

ESG is not only qualitative information that companies interested in the greater good present. It is information that also allows the firms to benefit economically. One of those benefits is associated with the company's lower cost of capital, better prediction in future financial performance, and lesser impact from systematic risk. Investors who do not consider ESG information mostly follow passive investment strategies and do not have or are unwilling to invest time researching ESG factors by asset classes, sectors, and industries (Amir \& Serafeim, 2018).

The ESG disclosure information supplements the financial statements. Investors can perceive a company's expected future financial performance and indicate the reasons behind the difference between the market and the book value (Serafeim \& Grewal, 2019).

Investors of large-to small firms are interested in socially responsible companies that disclose ESG for financial reasons. ESG is a strategic financial decision for the larger investment companies since more than $54 \%$ of their customer base demand this type of investment. $43 \%$ of investors are interested in the development of new investment products that include ESG factors. The decision is primarily ethical for smaller investors that look for changes in companies' behavior (Amir \& Serafeim, 2018).

Contrary to the belief that ESG investing causes less returns, others argue for higher returns. A positive correlation exists between corporate sustainability and market value for US non-financial firms (period 1999-2002 (Lo \& Sheu, 2007). The increase of operating performance, positive impact on labor productivity, and employee satisfaction for "stakeholder sensitive" companies create better value for shareholders (Flammer, 2015). 
Nagy et al. (2013) optimized portfolios with improved ESG rating while keeping risk, performance, country, industry, and style characteristics similar to conventional benchmarks, such as the MSCI World Index. Their results show that underweighting assets with low ESG ratings also raised portfolio performance during that period. The highest ESG rated assets had more uneven performance than the underweighted ones; they did better in periods of limited risk appetite during this volatile market cycle.

Incorporating the utility function and creating a Decision Support System to obtain the best portfolio from a universe of investment possibilities, an SRI portfolio is created with similar financial risk and return as a conventional one (Calvo et al., 2014). Incorporating ESG policies reduce bankruptcy risk. In case of financial difficulties, ESG companies recover faster than those that do not apply corporate social responsibility, a situation that is intensified when operating in a litigious business environment (Lin \& Dong, 2018).

Starks et al. (2017) argue that investors prefer companies that have higher ESG profiles for long-term horizon investments. Firms are under pressure to obtain higher investment if they consider or improve their ESG profiles. Companies that engage in higher sustainability practices stock returns outperform lower sustainability, attract long-term investors, and obtain higher analyst coverage (Serafeim \& Grawall, 2019).

Portfolios created using information from 23 years of about 3000 US companies and optimized using six different methods indicated that SRI investors' risk and returns depend on the optimization technique. Comparing SRI and conventional portfolios assumes a higher risk for SRI investing due to the complexity of ESG values. Nevertheless, an SRI portfolio using the Markowitz and
Black-Litterman methodology can produce higher risk-adjusted returns than risk parity methodologies (Oikonomou et al., 2018).

When filtering ESG companies before including them in a portfolio provides better returns. First, list the companies per industry and separate them into groups with higher and lower disclosure scores. The second filter is to choose firms whose returns have significant exposure to ESG. There is evidence of higher returns when using material industry-specific ESG items (Henriksson et al., 2019).

Kaiser \& Schaller (2019) studied ESG ratings in Europe related to strategies for carbon footprint as a central measure of a portfolio's environmental friendliness. The empirical results demonstrate that low environmental ratings for ESG-momentum portfolios obtain mixed results in risk-adjusted returns across alternative rating components.

Alessandrini \& Jondeau (2019) compared investment portfolio performance based on the before and after implementation of ESG policies. The finding suggests that companies that implement ESG standards improve their returns without deteriorating risk-return performances. Return improvement ranges from $20 \%$ for developed countries and up to $40 \%$ for emerging.

Pedersen et al. (2020) investigated the performances of three types of portfolios composed of companies all over the world. The first portfolio does not consider ESG, the second one with optional inclusion ESG, and the third one with a preference of ESG companies. The inclusion of ESG as a factor for portfolio selection offers an increased Sharpe ratio. The results indicate that investors tend to have a higher preference for companies with ESG in their portfolios.

Razmpa \& Kosowski (2020) conclude that investors can achieve both objectives - risk and performance while 
integrating ESG. Nevertheless, the country and industry sectors influence the outcome.

Academics differ on incorporating environmental, social, and governance (ESG) considerations into their investment process. Results are mixed concerning the performance of the portfolio when integrating ESG into investment strategies. There are different ESG investing styles. One style is to filter and avoid sin stocks and industries. Others use the best-in-class approach, and others integrate the ESG in their fundamental analysis (Serafeim \& Grewal, 2019).

This study evaluates and compares the risk and returns of ESG with non-ESG portfolios. The companies that form the portfolios are from the Australian ASX and Japan's Nikkei Index.

\section{METHODOLOGY}

The methodology for this study has two parts. The first part is related to the creation of regression models in order to find the relationship between market returns and accounting-based factors (ROA, ROE, P/E ratio, P/B ratio, Book Value), the market-based factor (WACC) and ESG of companies with and without ESG for each country (Australia and Japan).

The ESG score is a measurement that does not pretend to suggest decision making but to publish a performance benchmark of companies that have global standards. However, it is known by the market that companies with a high ESG score tend to have low exposure to systematic risk, lower volatility in their earnings, and lower capital costs (Wright et al., 2010). For this study, we use the Bloomberg platform as a source of information.

The second part is creating portfolios and comparing their risk-return performance using ESG, level of ESG disclosure score, market capitalization, and weight as a differentiator.

\section{Regression model based on ESG}

\section{Data}

The annual data of the companies from Australia's S\&P/ASX Index and Japan's Nikkei 225 Index, the covering period considered for the companies depends on the availability of data, from 2005 to 2019 and dividing them into two data panels: companies with and without ESG for each country.

Table 2. Summary of the companies listed for each countries' Data Panel.

\begin{tabular}{lll}
\hline & With ESG & Without ESG \\
\hline S\&P/ASX & 81 & 101 \\
Nikkei 225 & 63 & 162 \\
\hline
\end{tabular}

\section{Estimation Model}

According to (Hanck et al., 2018), regression using panel data may mitigate omitted variable bias when there is no complete information on variables correlated with the regression model. Therefore, the estimation of the model will be by adding fixed-effects regressions using entity fixed effects.

Panel data is longitudinal data that measures ESG and accounting information for several companies from Australia and Japan.
The development of the panel data regression model is based on a fixed-effects regression model. In order to test the hypothesis, this study uses panel regression. The model of this study is the following:

$Y_{i t}=\beta_{1} X_{i t}+\alpha_{i}+u_{i t}, i=1, \ldots, n, t=$ $1, \ldots, T, \quad$ (Eq. 1)

We assume the following: 
1. $u_{i}$ : is the error term and has conditional mean zero, that is, $E\left(X_{i 1}, X_{i 2}, \ldots, X_{i T}\right)$.

2. $\left(X_{i 1}, X_{i 2}, \ldots, X_{i 3}, u_{i 1}, \ldots, u_{i t}\right), i=$ $1, \ldots, n$ are i.i.d draws from their joint distribution.

3. Large outliers are unlikely; therefore, they have nonzero finite fourth moments.

4. There is no perfect multicollinearity. When there are multiple regressions, $X_{i t}$ is replaced by $X_{1, i t}, X_{2, i t}, \ldots, X_{k, i t}$.

The empirical study uses the Fixed Effects Regression Assumptions and Standard Errors for Fixed Effects Regression to help adjust the heteroskedasticity and autocorrelation consistent (HAC) standard errors. Therefore, Clustered Standard errors allow for heteroskedasticity and autocorrelated errors within an entity but not correlation across entities (Hanck et al., 2018).

This study aims to model the relationship between returns and accounting and market-based factors to prove any significance in the returns of companies when applying ESG and compare the significance in the returns of companies without ESG.

The fixed-effect model regression allows us to analyze the impact of variables that vary over time; each company has its characteristics that may influence the predictor variable. The model removes the effect of the time-invariant characteristics, and by consequence, we can get the net effect of the predictors. We use a data panel for our regression model to observe different entities' behavior across time. The data panel analysis allows us to control variables that are not observable, like business practices across companies. The objective of using this methodology is to reduce omitted variable bias.

\section{Fixed effect model regression}

The empirical study for the fixed effect model regression includes two regression models: companies with ESG for Australia and Japan; and companies without ESG for Australia and Japan.

\section{Measurements of variables}

In this study, the measurements of variables used are accounting-based and market-based factors as indicators of financial performance for each public company selected.

Independent Variable: The yearly stock return of the companies covering the data panel for Australia and Japan.

Dependent Variables: The dependent variables consist of the yearly information of ESG, WACC, ROA, ROE, P/E ratio, P/B ratio, and book value.

According to (Malik \& Handono, 2019), investors use financial indicators that can be either accounting or market-based for their investment decisions. For this study, the accounting-based measurements are:

Return on Assets (ROA) is the net income after tax divided by the total assets' end of the year. Companies are concerned about the efficiency of the assets utilization in the effort to improve financial performance. It is also recognized to measure new investments' profit contribution (Fridson \& Alvarez, 2011). The formula of ROA is the following:

$$
R O A=\left(\frac{\text { Net Income after taxes }}{\text { Total Assets }}\right) \times 100
$$

(Eq. 2)

Return on Equity (ROE) is a measure of how effectively management uses assets to create profits. Companies are concerned about how well they are on their financial performance. ROE is considered the return on net assets (Fridson \& Alvarez, 2011). The formula of ROE is the following:

$$
R O E
$$$$
=\left(\frac{\text { Net Income Available for Common Shareholders }}{\text { Average Total Common Equity }}\right)
$$

$\times 100$

(Eq.3)

The Price-to-Earnings ratio ( $\mathrm{P} / \mathrm{E}$ ratio) is the ratio for valuing a company that measures its current share price relative to its per-share earnings. This measurement $\mathrm{s}$ a company's real value in shares (Fridson \& Alvarez, 2011). The formula of the $\mathrm{P} / \mathrm{E}$ ratio is the following:

$$
P / E \text { Ratio }=\frac{\text { Current Share Price }}{\text { Earnings per Share }}
$$


(Eq.4)

The Price-to-Book ratio ( $\mathrm{P} / \mathrm{B}$ ratio) compares a firm's market capitalization to its book value. It measures the market's valuation of a company compared to its book value (Fridson \& Alvarez, 2011). The formula of the $\mathrm{P} / \mathrm{B}$ ratio is the following:

$$
P / B \text { Ratio }=\frac{\text { Market } \text { Price per Share }}{\text { Book Value Per Share }}
$$

Book Value is the difference between a company's total assets and total liabilities. Book Value indicates the total value of a company's assets that a shareholder would receive if liquidated (Fridson \& Alvarez, 2011). The formula of Book Value is the following:

Book Value $=$

(Total Common Shareholders Equity-Preferred Stock)

Number of Outstanding Common Shares

(Eq.6)

Moreover, the market-based measurement is WACC. The weighted average cost of capital (WACC) calculates a firm's capital cost, including common stocks, preferred stocks, bonds, and long-term debt (Fridson \& Alvarez, 2011). The formula for WACC is the following:

$$
\begin{aligned}
W A C C=[K D & \times(T D \div V)]+[K P \times(P \\
& \div V)]+[K E \times(E \div V)]
\end{aligned}
$$

(Eq.7)

where $K D=$ Cost of debt, $\quad T D=$ Total debt, $\quad V=$ Total debt + Preferred Equity + Equity Capital, $K P=$ Cost of preferred equity, $\quad P=$ Preferred equity, $K E=$ Cost of equity and, $E=$ Equity capital.

Finally, for the ESG factors, we used the Bloomberg database's ESG ratings only, including the ESG Disclosure Score, Environmental Disclosure Score, Social Disclosure Score, and Governance Disclosure Score. Bloomberg database rates the ESG Disclosure Score, summarizing the company level of disclosure on each factor. For the regression, the ESG Disclosure Score is normalized to the range of 0.1 to 100 . Statistical normalization is used to transform a variable's distribution to make comparisons for sets of elements (in this case, the independent variable) and eliminate the effects of influences.

\section{Selection Criteria}

ESG and firm performance data are from the Bloomberg database. Bloomberg reports detailed yearly ESG data. For collecting the data, Bloomberg's function was "EQS," which helped us filter the companies with and without ESG data from Australia's S\&P/ASX Index and Japan's Nikkei 225 Index. Once having the list of companies per country, the information was filtered depending on when the companies started to have ESG information. Both Australia and Japan's information are from 2005 to 2019. All annual data is based on the ESG reported date.

Weighting Scheme

The weighting scheme is an outcome of an optimization process. The optimized weighting relies on factor exposures for all securities and is the best combination to represent investor objectives. The optimization objective is to maximize the alpha score under various optimization constraints. The weighting scheme is the following:

$$
\begin{gathered}
\propto(i)=0.34 * F_{1}(i)+0.355 * F_{2}(i) \\
+0.305 * F_{3}(i)
\end{gathered}
$$

(Eq.8)

Where, $F_{1}(i)=$ Environmental Factor, $F_{2}(i)=$ Social Factor and, $F_{3}(i)=$ Governance Factor. Portfolio formation and evaluation criteria Our portfolio analysis compares the riskreturn relationship between portfolios that include companies that present their ESG information and others that omit them. The portfolios are evaluated and compared using fixed weight and market weight. Portfolio results are compared on performance and risk. The period of portfolio study is 2010-2019 with quarterly rebalances. Performance is evaluated based on accumulated returns, Sharpe ratio, Treynor ratio, and Jensen's alpha. The risk is evaluated based on standard deviation, beta, and VaR. 
Table 3. Summary of the companies listed for each country's portfolio.

\begin{tabular}{lll}
\hline & With ESG & Without ESG \\
\hline S\&P/ASX & 81 & 123 \\
Nikkei 225 & 63 & 146 \\
\hline
\end{tabular}

The performance of each portfolio is compared with a benchmark (conventional) or with risk-adjusted returns. The latter use the Sharpe ratio, Treynor ratio, and Jensen's alpha. The Sharpe ratio considers both systematic risk and unsystematic risk (standard deviation) and measures the excess returns per unit of risk (Sullivan, 2006).

The formula of Sharpe ratio:

$$
\text { Sharpe ratio }=\frac{\overline{r_{p}}-r_{f}}{\sigma_{p}}
$$

(Eq. 9)

$\overline{r_{p}}=$ Expected return of the portfolio or investment

$r_{f}=$ Risk-free rate

$\sigma_{p}=$ Standard deviation of portfolio returns

The Treynor ratio calculates the excess return per unit of systematic risk (beta) (Scholz \& Wilkens, 2005). Both ratios are used for comparison purposes in portfolio evaluation. Higher ratios indicate higher returns for a unit of risk.

The formula of Treynor ratio:

$$
T=\frac{r_{p}-r_{f}}{\beta_{p}}
$$

(Eq. 10)

$T=$ Treynor Ratio

$r_{p}=$ Portfolio's return

$r_{f}=$ Risk-free rate

$\beta_{p}=$ beta of the portfolio

Jensen's alpha compares the portfolio performance to a benchmark, quantifies the difference (alpha). A positive alpha indicates Consistent the portfolio returns have been historically. The higher the standard deviation, the higher the risk of the portfolio. that the portfolio outperforms the benchmark, and a negative that underperforms the benchmark. The alpha can be positive, negative, or zero (Scholz \& Wilkens, 2005)

The formula of Jensen's alpha:

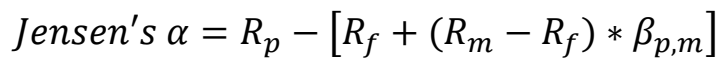

(Eq. 11)

$R_{p}=$ return of the portfolio

$R_{f}=$ Risk-free rate

$R_{m}=$ return of the market

$\beta_{p, m}=$ sensitivity of the portfolio returns vs. market returns

Value at Risk (VaR) measures and quantifies in monetary units a loss that a portfolio can incur during a period with a certain confidence level. The versatility of VaR stems from the use of monetary units, the different holding periods of analysis, and probability distributions (Jorion 2002)

Formula VaR:

$$
V A R=\left[r_{p}-\left(z * \sigma_{p}\right)\right] V_{p}
$$

(Eq. 12)

Note: Daily $r_{p}$ is typically assumed to be 0 .

1. A portfolio expected return $\left(r_{p}\right)$, (ie. higher $r_{p}=$ lower VAR.

2. A portfolio standard deviation $\left(\sigma_{p}\right)$, (i.e. more correlated returns $=$ higher VAR).

3. A probability level (z)

Standard deviation measures the volatility of a portfolio; it is the deviation from the mean returns. The standard deviation indicates how

Formula Standard deviation: 


$$
s=\sqrt{\frac{\sum(X-\bar{x})^{2}}{n-1}}
$$

(Eq. 13)

$X=$ The value in the data distribution

$\bar{x}=$ The sample mean

$n=$ Total number of observations

The portfolio beta measures the systematic risk of an investment. For a portfolio, it is the weighted average of all individual stocks included in the portfolio. A portfolio beta less than 1 indicates a lower systematic risk than the benchmark.

Formula beta:

$$
\beta_{p}=\frac{\operatorname{Cov}\left(r_{p}, r_{b}\right)}{\operatorname{Var}\left(r_{b}\right)}
$$

(Eq. 14)

This study compares the risk and returns of portfolios in three phases:

Phase I: Compare portfolio performance ALL ESG vs. ALL non ESG.

Phase II: Compare portfolio performance between portfolios with ESG vs. non ESG using different market capitalization percentiles $(0.25,0.50,0.75)$. We name the 0.25 percentile Low $25 \%$ the 0.75 percentile High $25 \%$. The 0.50 is separated in the Low $50 \%$ and High $50 \%$.

Phase III: Compare portfolio performance between companies that report ESG only using different ESG percentiles (0.25, 0.50, 0.75). We name the 0.25 percentile Low $25 \%$ the 0.75 percentile High $25 \%$. The 0.50 is separated in the Low 50\% and High 50\%.

This study aims to prove that portfolios that include ESG disclosing companies outperform the benchmark and the non-ESG companies in returns and have a lower risk.

\section{Results}

We used a fixed effect regression model for these data panel study tests to identify any significant change in returns when applying ESG. We used the independent and dependent variables to confirm a significant change to achieve proper findings, following the methodology. A regression was run for the two countries separately with and without ESG.

The fixed regression model confirms a significant change in the study countries when the ESG policies are applied. A brief explanation is made according to the regression models' results to assess ESG performance's impact on the market. Additionally, the results show factors that investors consider in their investment strategies. It must be noted that the factors and their significance change depending on the country and if the companies have ESG policies.

Regression results per country

Each country consists of two fixed effect regressions: the significant cumulative results for each year of the period established for companies with and without ESG and the significant results for the entire period for companies with and without ESG for each country.

The tables shown in the Appendix allow us to observe the change in the factors' significance when adding one more year to our data sample. We can observe the impact of ESG on market returns. The ESG is significant for Japan for only one year due to market adjustments. For Australia, the ESG impacts companies' returns for more than one period; this corresponds to ESG Momentum. The table allows us to observe how ESG policies and the scores' changes are drivers for returns.

Concerning the tables contemplating the entire period for companies with ESG and without ESG for each country, we can observe which factors to consider when creating investing strategies. When comparing the companies that include ESG, we can observe that investors consider more factors when investing in these companies. Investors that consider investing in companies with ESG seek risk management factors to mitigate exposure and naturally bid up a company's price that gives them a better return on their investment.

\section{Australia}

We run annual regressions of yearly observations to test the significance of the variables corresponding to market returns of 
companies in Australia's S\&P/ASX from 2005 to 2019. Each column is cumulative in data considering the years before the observed year. The model shows the influence of ESG factors on the market value of Australian companies.

The ESG factor coefficient is statistically significant more than once in the observed range of time; its confidence level varies from $90 \%$ to $99 \%$. The significance of coefficients in different years corresponds to ESG momentum, the implementation of ESG policies, and the scores' changes as drivers for the returns. ESG momentum is overweight stocks with improving ESG ratings.

The ESG momentum premise is that future stock performance is linked to the company's ESG quality and a reduction in potential future liabilities, which eventually will be discounted by the market. The ESG policies influenced how equity markets priced stocks for more than one period; the market reacted to a change in rating in the short term. The ESG factor has negative results since it depends on the year we observe if its relationship with the market return is negative.

When observing the cumulative of all the observed data in 2019 in table 4 for firms with ESG, the ESG, EDS, GDS, P/E ratio, and book value are statistically significant. Furthermore, in table 5 for firms without ESG, the WACC and P/B ratio are statistically significant.

Table 4. Summary of factors influencing returns of firms in Australia with ESG.

\begin{tabular}{lllll}
\hline Year & Estimate & Standard Error & T Value & P value \\
\hline ESG & $-3.4507 \mathrm{e}-02$ & $1.5412 \mathrm{e}-02$ & -2.2389 & $0.0253557 *$ \\
ENV & $1.6887 \mathrm{e}-02$ & $7.4296 \mathrm{e}-03$ & 2.2729 & $0.0232217 *$ \\
SOCIAL & $3.8185 \mathrm{e}-03$ & $4.5893 \mathrm{e}-03$ & 0.8320 & 0.4055577 \\
GOV & $1.5082 \mathrm{e}-02$ & $4.4363 \mathrm{e}-03$ & 3.3997 & $0.0006982 * * *$ \\
WACC & $-1.4621 \mathrm{e}-04$ & $5.5765 \mathrm{e}-04$ & -0.2622 & 0.7932158 \\
PER & $4.9452 \mathrm{e}-05$ & $1.4581 \mathrm{e}-05$ & 3.3916 & $0.0007191 * * *$ \\
ROA & $6.1657 \mathrm{e}-03$ & $6.9417 \mathrm{e}-03$ & 0.8882 & 0.3746168 \\
ROE & $-1.7183 \mathrm{e}-03$ & $4.0053 \mathrm{e}-03$ & -0.4290 & 0.6679970 \\
PX2B & $1.9306 \mathrm{e}-03$ & $1.3602 \mathrm{e}-03$ & 1.4193 & 0.1560805 \\
BV & $-6.6389 \mathrm{e}-03$ & $2.1752 \mathrm{e}-03$ & -3.0521 & $0.0023261 * *$ \\
\hline Note: Significance codes: $0^{* * * * \prime} 0.001^{* * *} 0.01^{* *} 0.05^{\prime \prime} 0.1^{\prime \prime} 1$ & &
\end{tabular}

Table 5. Summary of factors influencing returns of firms in Australia without ESG.

\begin{tabular}{lllll}
\hline Year & Estimate & Standard Error & T Value & P value \\
\hline WACC & $1.2021 \mathrm{e}-03$ & $3.2061 \mathrm{e}-04$ & 3.7494 & $0.000188 * * *$ \\
PER & $-5.6711 \mathrm{e}-06$ & $8.4801 \mathrm{e}-06$ & -0.6687 & 0.503819 \\
ROA & $-3.4506 \mathrm{e}-04$ & $1.0606 \mathrm{e}-04$ & -3.2536 & $0.00118 * *$ \\
ROE & $1.7721 \mathrm{e}-04$ & $6.3863 \mathrm{e}-05$ & 2.7749 & $0.005631 * *$ \\
PX2B & $-6.6358 \mathrm{e}-04$ & $2.1272 \mathrm{e}-04$ & -3.1196 & $0.001866 * *$ \\
BV & $-9.9251 \mathrm{e}-04$ & $4.2124 \mathrm{e}-04$ & -2.3561 & $0.018669 *$ \\
\hline Note: Significance codes: $0^{* * * *} 0.0011^{* *} 0.01^{* \prime} 0.05^{\prime \prime}{ }^{\prime \prime} 0.1^{\prime \prime} 1$ & &
\end{tabular}

Table 4 summarizes the descriptive statistics of the main variables influencing market performance for Australian companies with ESG disclosure scores. The figure incorporates the significance of factors for all the observed data from 2005 to 2019. The table reports the estimate, standard error, $\mathrm{t}$-value, $\mathrm{p}$ value, and significance level. Significant 
estimates use the t-statistic and the p-value; the $\mathrm{p}$-value must be lower than 0.05 , and our tstatistic absolute value must be higher than 1.96.

The ESG has a negative coefficient that is statistically significant by a $95 \%$ confidence level. The standard error shows that the estimated coefficient can differ 0.015412 from the actual value. The environmental factor indicates a significant positive relationship at a 0.05 level. The governance factor shows a significant positive relationship by a $99 \%$ confidence level. The $\mathrm{P} / \mathrm{E}$ ratio has a positive correlation with the returns by a $99 \%$ significance level. Moreover, the book value coefficient indicates a significant negative relationship at a 0.01 level.

Considering companies with ESG, investors in Australia are interested in ESG policies and the efficiency in company management.

Table 5 summarizes the descriptive statistics of the main factors influencing Australian companies' market performance without ESG. The figure shows the cumulative significance of the factors influencing firms' returns for 2005 to 2019 . We must note that investors who consider companies without ESG in their portfolio find the WACC as a positive coefficient (statistically significant at 99\% confidence level) and the P/B ratio as a negative coefficient (statistically significant at 98\% confidence level). The connection between the WACC and the P/B ratio is the risk associated with the investment. Investors who consider companies without ESG moved from a compliance mindset to a risk mitigation approach. When analyzing the confidence interval, the ROE is in the $98 \%$ interval. The ROE is observing how efficiently management is using a company investment to create profits.

The ROA has a negative coefficient that is statistically significant by a $98 \%$ confidence level. The book value coefficient indicates a significant negative relation at a 0.05 level. The coefficients of ROA and book value are significant. We can tell how much the factors contribute to predicting the variation in the dependent variable and how they are negatively correlated. The P/B ratio was statistically significant, with a $98 \%$ confidence level, negatively correlated with the market return meaning that investors do not tend to mitigate risk in their portfolios.

Japan

Table A2 from the Appendix shows the relationship of 7 variables that affect companies' returns with ESG in Japan. The seven variables reflect firm-level characteristics and are observed yearly from 2005 to 2019; 2005 will not be considered since there is no significance. We can measure variables observed for several entities across time with the panel data and observe significance in our dependent variable called returns. Each column is cumulative in data considering the years before the observed year.

In 2007, the ESG coefficient was statistically significant, with a confidence level of $99 \%$. As the coefficient is different from zero, there is a genuine and significant relationship between ESG policies and market performance. ESG has a negative relationship with the market performance of firms in Japan. The ESG was not significant instantly when the policies implementation; this is consistent since ESG policies' implementation does not impact the short-term. The ESG coefficient is significant once it has to do with the financial market adjustment process.

In table 6 the statistically significant variables for all the cumulative data can be seen in 2019 for firms in Japan with ESG are the $\mathrm{P} / \mathrm{E}$ ratio, $\mathrm{ROA}, \mathrm{P} / \mathrm{B}$ ratio, and the book value. Furthermore, in Table 7 the statistically significant variables for firms without ESG are the WACC, P/E ratio and book value.

Table 6. Summary of factors influencing returns of firms in Japan with ESG.

\begin{tabular}{lllll}
\hline Year & Estimate & Standard Error & T Value & P value \\
\hline ESG & $-1.7895 \mathrm{e}-03$ & $2.7351 \mathrm{e}-02$ & -0.0654 & 0.9478483 \\
ENV & $4.0180 \mathrm{e}-04$ & $1.7019 \mathrm{e}-02$ & 0.0236 & 0.9811701 \\
\hline
\end{tabular}




\begin{tabular}{lllll}
\hline SOCIAL & $6.2711 \mathrm{e}-04$ & $6.8248 \mathrm{e}-03$ & 0.0919 & 0.9268091 \\
GOV & $3.0456 \mathrm{e}-03$ & $6.8750 \mathrm{e}-03$ & 0.4430 & 0.6578779 \\
WACC & $2.7368 \mathrm{e}-04$ & $4.3932 \mathrm{e}-04$ & 0.6229 & 0.5334820 \\
PER & $-5.3336 \mathrm{e}-06$ & $3.2822 \mathrm{e}-07$ & -16.2505 & $<2.2 \mathrm{e}-16 * * *$ \\
ROA & $-1.5505 \mathrm{e}-02$ & $4.6075 \mathrm{e}-03$ & -3.3652 & $0.0007984 * * *$ \\
ROE & $-1.7568 \mathrm{e}-05$ & $1.5914 \mathrm{e}-03$ & -0.0110 & 0.9911945 \\
PX2B & $3.31 \mathrm{e}-02$ & $1.9131 \mathrm{e}-02$ & 1.7314 & 0.0837378. \\
BV & $-6.3385 \mathrm{e}-03$ & $1.4724 \mathrm{e}-03$ & -4.3050 & $1.859 \mathrm{e}-05 * * *$ \\
\hline Note: Significance codes: $0^{-* * * *} 0.001^{-* *} 0.01^{* *} 0.05^{\prime \prime} \prime 0.1^{\prime \prime} 1$ & &
\end{tabular}

Table 7. Summary of factors influencing returns of firms in Japan without ESG.

\begin{tabular}{lllll}
\hline Year & Estimate & Standard Error & T Value & P value \\
\hline WACC & $-5.4176 \mathrm{e}-04$ & $9.3994 \mathrm{e}-05$ & -5.7637 & $9.485 \mathrm{e}-09$ *** \\
PER & $-1.2020 \mathrm{e}-06$ & $5.3642 \mathrm{e}-07$ & -2.2408 & $0.025144 *$ \\
ROA & $7.2759 \mathrm{e}-05$ & $7.8275 \mathrm{e}-05$ & 0.9295 & 0.352727 \\
ROE & $-1.7931 \mathrm{e}-05$ & $1.9790 \mathrm{e}-05$ & -0.9061 & 0.365006 \\
PX2B & $-1.6991 \mathrm{e}-05$ & $6.1915 \mathrm{e}-05$ & -0.2744 & 0.783792 \\
BV & $1.7044 \mathrm{e}-04$ & $6.1514 \mathrm{e}-05$ & 2.7707 & $0.005644 * *$ \\
\hline
\end{tabular}

Table 6 incorporates descriptive statistics of the main factors influencing Japanese companies' market performance with ESG. The figure shows the cumulative significance of the factors influencing firms' returns with ESG in Japan from 2005 to 2019.

The results demonstrate that the P/E ratio, ROA, and book value are statistically significant with a $99 \%$ confidence level and the $\mathrm{P} / \mathrm{B}$ ratio with a $90 \%$ significance level.

Another indicator that we must consider is the standard deviation, which measures the estimated coefficient's average coefficient from its actual value. Therefore, the lower the standard deviation, the better.

The P/E ratio, ROA, and book value have a negative relationship with the market return, which implies how much the factors contribute to predicting the variation in the dependent variable, and it has to do with the fact that these coefficients referred to the efficiency of asset management to generate income.

The P/B ratio has a positive relationship with market returns. This indicator is used to compare the business net assets available about its stock's sales price; an investor who considers this factor for their investment decisions seeks to observe risk.

Table 7 incorporates descriptive statistics of the main factors influencing
Japanese companies' market performance without ESG. The figure shows the cumulative significance of the factors influencing firms' returns for 2005 to 2019.

The results demonstrate that the WACC has a negative relationship, with a 99\% confidence level with the market return, which implies that investors who consider companies with EDS in their portfolios tend to mitigate risk. As well, the $\mathrm{P} / \mathrm{E}$ ratio coefficient indicates a significant negative relation at a 0.05 level.

The book value is statistically significant, with a $98 \%$ confidence level. The book value indicates the value of the shareholders' equity according to the financial statements; it determines the company's real value. This indicator represents the total amount a company would be worth if it liquidated all its assets and paid all its liabilities. Therefore, the positive relationship between book value and market returns makes sense. The book value does not always include the full impact of claims on assets and the cost of selling them. Also, it does not consider the fact that market value continually changes in the marketplace.

Portfolio results per country

The performance of the portfolios is compared to the S\&P benchmark in the three evaluation phases. Fixed and value-weighted 
portfolios are created for each phase, using market capitalization and ESG disclosure scores as filters. The results are for the period 2010-2019. The benchmark used is the S\&P
500, and the currency is USD. In Table 8, we can see the S\&P risk-return performance for 2010-2019.

Table 8. $S \& P$ Benchmark results.

\begin{tabular}{lllll}
\hline Total Return \% & Mean annualized return\% & Sharpe ratio & Standard deviation & VaR \\
\hline 209.90 & 20.97 & 0.97 & 14.36 & -1.44 \\
\hline
\end{tabular}

Portfolio's Phase 1:

In the first phase, we compare portfolio risk-return performance and filter using the ESG disclosure scores. In order to avoid the financial crisis of 2007-2009, we further filtered the data used in the regression analysis to include only companies that disclosed ESG scores after 2010 (Table 9). The value-weighted portfolios apply a higher weight on larger market capitalization companies. A total of eight portfolios (four per country) are analyzed.

Table 9. Data filtering for Phase 1 portfolios.

\begin{tabular}{lll}
\hline & Companies with ESG & Companies without ESG \\
\hline S\&P/ASX from 2005 & 81 & 101 \\
S\&P/ASX from 2010 & 59 & 79 \\
Nikkei 225 from 2005 & 63 & 163 \\
Nikkei 225 from 2010 & 60 & 155 \\
\hline
\end{tabular}

Tables 10 and 11 show the best and worst-performing portfolios per country of portfolios, ALL ESG vs. ALL non-ESG. Although there are differences between the risk-return results of the two countries, we see that the best return results are from the valueweighted of ALL non-ESG portfolios and the worst from the value-weighted ESG portfolios. Similar results are for the Sharpe ratio, Treynor ratio, and Jensen's alpha.

In Australia, both ALL non-ESG portfolios outperform both the benchmark and ALL ESG portfolios. Australia's best return performance portfolio (value-weighted ALL non-ESG) outperforms the worst return performance (All ESG value-weighted) by almost $20 \%$ annually over the period 20102019. The ALL non-ESG portfolio has a higher Sharpe ratio than the benchmark and all other fixed and value-weighted portfolios. Comparing the Treynor ratio of the four Australian portfolios indicated that this portfolio has the highest excess return per unit of systematic risk.

None of the Japanese portfolios outperformed the benchmark. The best performance portfolio outperforms by $2 \%$ annually the worst return performing. Its Sharpe ratio is lower than the benchmark's and lower than three out of four of Australia's portfolios. Nevertheless, the Treynor ratio outperforms all seven portfolios.

Both countries' ALL non-ESG portfolios outperform the ALL ESG portfolios. However, irrelevant of the portfolio type, they all had a positive alpha and overperformed the predicted returns.

Table 10. Best ALL ESG vs. ALL non-ESG portfolio returns results.

\begin{tabular}{lccrrrrr}
\hline Country & ESG & Weight & $\begin{array}{l}\text { Total } \\
\text { Return \% }\end{array}$ & $\begin{array}{l}\text { Mean } \\
\text { annualized } \\
\text { return \% }\end{array}$ & $\begin{array}{l}\text { Sharpe } \\
\text { ratio }\end{array}$ & Treynor & $\begin{array}{l}\text { Jensen } \\
\text { Alpha }\end{array}$ \\
\hline AUS & No & Value & 421.2237 & 34.0573 & 0.9957 & 0.6418 & 17.7640 \\
\hline
\end{tabular}




\begin{tabular}{llllllll}
\hline JPN & No & Value & 131.2306 & 16.6006 & 0.6039 & 2.0795 & 10.2603 \\
\hline
\end{tabular}

Table 11. Worst ALL ESG vs. ALL non-ESG portfolio returns results.

\begin{tabular}{lccrrrrr}
\hline Country & ESG & Weight & $\begin{array}{l}\text { Total } \\
\text { Return \% }\end{array}$ & $\begin{array}{l}\text { Mean } \\
\text { annualized } \\
\text { return \% }\end{array}$ & $\begin{array}{l}\text { Sharpe } \\
\text { ratio }\end{array}$ & Treynor & \multicolumn{2}{l}{$\begin{array}{l}\text { Jensen } \\
\text { Alpha }\end{array}$} \\
\hline AUS & Yes & Value & 100.3066 & 14.2327 & 0.4957 & 0.2580 & 4.2965 \\
JPN & Yes & Value & 74.3793 & 12.0106 & 0.3999 & 0.9439 & 6.6792 \\
\hline
\end{tabular}

Tables 12 and 13 show the lowest and highest risk portfolios. All eight portfolios compared had a higher standard deviation and VaR than the benchmark.

The portfolio with the highest return has the highest standard deviation for Australia, whereas Japan is precisely the opposite. The highest return portfolio had the lowest standard deviation, lowest VaR, and beta. The Japanese portfolio betas are positive but and very low compared to the Australian.

The lowest risk portfolio for Australia is the non-ESG fixed weighted non ESG. For both countries, the ALL non-ESG portfolios have the lesser risk with the highest returns.

Table 12. Best ALL ESG vs. ALL non-ESG portfolio risk results.

\begin{tabular}{lllrrr}
\hline Country & ESG & Weight & $\begin{array}{l}\text { Standard } \\
\text { deviation }\end{array}$ & VAR 95\% & \multicolumn{2}{c}{ Beta } \\
\hline AUS & No & Fixed & 18.4225 & -1.8158 & 0.3469 \\
JPN & No & Value & 18.2144 & -1.7386 & 0.0529 \\
\hline
\end{tabular}

Table 13. Worst ALL ESG vs. ALL non-ESG portfolio risk results.

\begin{tabular}{lllrrr}
\hline Country & ESG & Weight & $\begin{array}{l}\text { Standard } \\
\text { deviation }\end{array}$ & VAR 95\% & \multicolumn{2}{c}{ Beta } \\
\hline AUS & No & Value & 22.8060 & -2.2476 & 0.3538 \\
JPN & Yes & Fixed & 20.0641 & -1.9310 & 0.0928 \\
\hline
\end{tabular}

Portfolio Phase 2:

In the second phase, we continue to compare ALL ESG vs. ALL non-ESG portfolios at different percentiles. The valueweighted portfolios apply a higher weight on larger market capitalization companies. A total of 32 portfolios are analyzed (16 per country). Table 14 shows the number of companies in each portfolio.
The portfolios comparison is as follows:

a. ESG Low $25 \%$ vs non-ESG Low $25 \%$ market capitalization

b. ESG High $25 \%$ vs non-ESG High $25 \%$ market capitalization

c. ESG Low $50 \% \%$ vs non-ESG Low $50 \%$ market capitalization

Table 14. Data filtering for Phase 2 portfolios- Constituents reporting ESG as of 2010 filtered by Market Capitalization

\begin{tabular}{llllll}
\hline & \multicolumn{3}{c}{ Australia S\&P/ASX } & \multicolumn{2}{c}{ Japan Nikkei 225 } \\
\hline Market cap. & $\begin{array}{l}\text { With } \\
\text { ESG }\end{array}$ & $\begin{array}{l}\text { Without } \\
\text { ESG }\end{array}$ & $\begin{array}{l}\text { Market } \\
\text { cap. }\end{array}$ & With ESG & $\begin{array}{l}\text { Without } \\
\text { ESG }\end{array}$ \\
\hline Index & 59 & 79 & & 60 & 155
\end{tabular}




\begin{tabular}{lllllll} 
LMCAP 25\% & $\leq 1,036.92$ & 15 & 20 & $\leq 4,566.04$ & 15 & 39 \\
HMCAP 25\% & $\geq 7,083.53$ & 15 & 17 & $\geq 20,293.40$ & 15 & 39 \\
LMCAP 50\% & $\leq 2,564.15$ & 30 & 40 & $\leq 9,010.25$ & 30 & 78 \\
HMCAP 50\% & $>2,564.15$ & 29 & 39 & $>9,010.25$ & 30 & 77 \\
\hline
\end{tabular}

Note: Market capitalization is in millions of USD.

The best performing Australian portfolios consistently outperform the benchmark, precisely the opposite of Japan's, where none of the portfolios outperform the benchmark. Australia's best return performance portfolio outperforms the worst return performance between $12 \%$ and $20 \%$ annually over 2010-2019. The difference is not as high for Japan, where the best return performance portfolio outperforms the worst return performance between $2 \%-5 \%$ annually.

The $25 \%$ high market capitalization ESG reporting companies in fixed-weighted portfolios obtain better returns in their categories. Best-performing portfolios are non-ESG reporting and value-weighted (Table 15). The returns and Sharpe ratio of the Japanese portfolios are consistently lower than the Australian; nevertheless, their Treynor ratio is higher. Irrelevant of the portfolio type, they all had a positive alpha and over performed the predicted returns. Australian lower and higher $25 \%$ portfolios obtain the highest returns, whereas Japan is the high market cap companies.

Table 15. Best ESGMCAP vs. non-ESGMCAP portfolio returns results.

\begin{tabular}{lllllllll}
\hline Country & Portfolio & $\begin{array}{l}\text { ES } \\
\text { G }\end{array}$ & Weight & $\begin{array}{l}\text { Total } \\
\text { return \% }\end{array}$ & $\begin{array}{l}\text { Mean } \\
\text { annualized } \\
\text { return\% }\end{array}$ & $\begin{array}{l}\text { Sharpe } \\
\text { ratio }\end{array}$ & $\begin{array}{l}\text { Treyno } \\
\text { r }\end{array}$ & $\begin{array}{l}\text { Jensen } \\
\text { Alpha }\end{array}$ \\
\hline AUS & LMCAP 25\% & No & Value & 584.8835 & 40.1089 & 1.1411 & 0.7513 & 21.7048 \\
AUS & HMCAP 25\% & Yes & Fixed & 508.7832 & 37.6778 & 1.0624 & 0.8832 & 21.1124 \\
AUS & LMCAP 50\% & No & Value & 400.3782 & 32.1476 & 1.0652 & 0.6122 & 16.5536 \\
AUS & HMCAP 50\% & No & Value & 445.3750 & 35.2393 & 1.0060 & 0.6632 & 18.5362 \\
JPN & LMCAP 25\% & No & Value & 49.6031 & 9.6140 & 0.3032 & 0.8276 & 5.1328 \\
JPN & HMCAP 25\% & Yes & Fixed & 160.3766 & 18.8259 & 0.6807 & 4.5105 & 12.1305 \\
JPN & LMCAP 50\% & No & Value & 84.4288 & 13.1179 & 0.4302 & 1.1101 & 7.5222 \\
JPN & HMCAP 50\% & Yes & Fixed & 147.0848 & 17.8428 & 0.6465 & 3.1457 & 11.3220 \\
\hline
\end{tabular}

Table 16. Worst ESGMCAP vs. non-ESGMCAP portfolio returns results.

\begin{tabular}{lllllllll}
\hline Country & Portfolio & ESG & Weight & $\begin{array}{l}\text { Total } \\
\text { return } \%\end{array}$ & $\begin{array}{l}\text { Mean } \\
\text { annualized } \\
\text { return\% }\end{array}$ & $\begin{array}{l}\text { Sharpe } \\
\text { ratio }\end{array}$ & Treynor & $\begin{array}{l}\text { Jensen } \\
\text { Alpha }\end{array}$ \\
\hline AUS & LMCAP 25\% & Yes & Fixed & 158.5214 & 19.3566 & 0.6301 & 0.4004 & 8.3845 \\
AUS & HMCAP 25\% & No & Value & 77.7279 & 11.7278 & 0.4365 & 0.2200 & 2.7886 \\
AUS & LMCAP 50\% & Yes & Fixed & 130.6143 & 20.1521 & 0.5647 & 0.3398 & 6.7007 \\
AUS & HMCAP 50\% & Yes & Fixed & 74.7214 & 31.8720 & 1.3277 & 1.2513 & 17.8617 \\
JPN & LMCAP 25\% & Yes & Fixed & 3.8885 & 4.6762 & 0.1140 & 0.1975 & 0.7940 \\
JPN & HMCAP 25\% & No & Value & 142.4967 & 17.4415 & 0.6381 & 2.5674 & 10.9444 \\
JPN & LMCAP 50\% & Yes & Fixed & 42.4455 & 9.3391 & 0.2708 & 0.4758 & 4.2268 \\
JPN & HMCAP 50\% & Yes & Fixed & 135.2901 & 16.9947 & 0.6102 & 2.0531 & 10.5021 \\
\hline
\end{tabular}


All best-performing portfolios have a higher standard deviation and VaR than the benchmark. These portfolios are less volatile compared to other portfolios in their categories. Nonetheless, all portfolios have positive betas, creating smaller portfolios and filtering with market capitalization the beta decreases from the larger portfolios in Phase 1. More volatile portfolios have greater VaR.

The portfolios projected for higher losses are the LMCAP25\%; for Australia is the non-ESGMCAP value-weighted portfolio, whereas, for Japan, it is the ESGMCAP fixed weighted.

Table 17. Best ESGMCAP vs. non-ESGMCAP portfolio risk.

\begin{tabular}{lllllll}
\hline Country & Portfolio & ESG & Weight & $\begin{array}{l}\text { Standard } \\
\text { deviation }\end{array}$ & VaR 95\% & Beta \\
\hline AUS & LMCAP 25\% & Yes & Fixed & 20.3102 & -1.9991 & 0.2986 \\
AUS & HMCAP 25\% & No & Value & 17.5106 & -1.8059 & 0.3475 \\
AUS & LMCAP 50\% & Yes & Fixed & 19.1161 & -1.9364 & 0.3284 \\
AUS & HMCAP 50\% & No & Value & 15.2283 & -1.4381 & 0.1616 \\
JPN & LMCAP 25\% & No & Value & 20.3691 & -1.9900 & 0.0746 \\
JPN & HMCAP 25\% & No & Value & 18.1379 & -1.7412 & 0.0451 \\
JPN & LMCAP 50\% & No & Value & 20.0027 & -1.9411 & 0.0775 \\
JPN & HMCAP 50\% & No & Value & 18.1168 & -1.7304 & 0.0492 \\
\hline
\end{tabular}

Table 18. Worst ESGMCAP vs. non-ESGMCAP portfolio risk.

\begin{tabular}{|c|c|c|c|c|c|c|}
\hline Country & Australia & ESG & Weight & $\begin{array}{l}\text { Standard } \\
\text { deviation }\end{array}$ & VaR $95 \%$ & Beta \\
\hline AUS & LMCAP $25 \%$ & No & Value & 26.1922 & -2.5394 & 0.3698 \\
\hline AUS & HMCAP $25 \%$ & Yes & Fixed & 23.6077 & -2.2442 & 0.2840 \\
\hline AUS & LMCAP 50\% & No & Value & 20.5029 & -2.0338 & 0.3431 \\
\hline AUS & HMCAP $50 \%$ & No & Value & 23.3450 & -2.2909 & 0.3541 \\
\hline JPN & LMCAP $25 \%$ & Yes & Fixed & 23.8331 & -2.3892 & 0.1359 \\
\hline JPN & HMCAP $25 \%$ & No & Value & 18.3901 & -1.6734 & 0.0278 \\
\hline JPN & LMCAP 50\% & Yes & Fixed & 20.5428 & -1.9889 & 0.0873 \\
\hline JPN & HMCAP $50 \%$ & Yes & Fixed & 18.4690 & -1.7544 & 0.0549 \\
\hline
\end{tabular}

Portfolio Phase 3:

In the third phase, we compare only ESG portfolios at different percentiles. All portfolios are value-weighted with a higher weight on higher ESG disclosure score companies. A total of eight portfolios (four per country) are analyzed. The portfolio comparison is as follows:

a. ESG Low $25 \%$ vs non-ESG Low $25 \%$

b. ESG High $25 \%$ vs non-ESG High $25 \%$

c. ESG Low $50 \%$ vs non-ESG Low $50 \%$

Analyzing performance, the only ESG portfolio that outperformed the benchmark is Japan's Low25\% (Tables
19 and 20). ESG based portfolios provide positive returns that underperform other types of investments and the benchmark. However, all portfolios' alpha is positive, indicating better than expected returns. 
Table 19. Best ESG portfolio returns results.

\begin{tabular}{|c|c|c|c|c|c|c|}
\hline Country & & $\begin{array}{l}\text { Total } \\
\text { Return \% }\end{array}$ & $\begin{array}{l}\text { Mean } \\
\text { annualized } \\
\text { return \% }\end{array}$ & $\begin{array}{l}\text { Sharpe } \\
\text { ratio }\end{array}$ & Treynor & $\begin{array}{l}\text { Jensen } \\
\text { Alpha }\end{array}$ \\
\hline AUS & Low $25 \%$ & 190.5535 & 21.5976 & 0.6992 & 0.4761 & 10.1729 \\
\hline JPN & Low $25 \%$ & 347.1512 & 37.1035 & 0.7160 & 4.1367 & 23.8706 \\
\hline
\end{tabular}

Table 20. Worst ESG portfolio returns results.

\begin{tabular}{|c|c|c|c|c|c|c|}
\hline Country & & $\begin{array}{l}\text { Total } \\
\text { Return \% }\end{array}$ & $\begin{array}{l}\text { Mean } \\
\text { annualized } \\
\text { return \% }\end{array}$ & $\begin{array}{l}\text { Sharpe } \\
\text { ratio }\end{array}$ & Treynor & $\begin{array}{l}\text { Jensen } \\
\text { Alpha }\end{array}$ \\
\hline AUS & High $25 \%$ & 48.9256 & 9.3011 & 0.3034 & 0.1512 & 0.4528 \\
\hline JPN & High $50 \%$ & 72.9491 & 12.3226 & 0.3831 & 0.7466 & 6.5480 \\
\hline
\end{tabular}

In ESG strategy investing, the least volatile portfolio and the least $\mathrm{VaR}$ losses are the ones that include all ESG reporting companies without filtering the percentiles of ESG disclosure scores (Tables 21 and 22).

Table 21. Best ESG portfolio risk results.

\begin{tabular}{lllll}
\hline Country & & $\begin{array}{l}\text { Standard } \\
\text { deviation }\end{array}$ & VAR 95\% & Beta \\
\hline AUS & S\&P/ASX & 18.9092 & -1.9207 & 0.3634 \\
JPN & Nikkei 225 & 19.6035 & -1.8806 & 0.0831 \\
\hline
\end{tabular}

Table 22. Worst ESG portfolio risk results.

\begin{tabular}{|c|c|c|c|c|}
\hline Country & & $\begin{array}{l}\text { Standard } \\
\text { deviation }\end{array}$ & VAR 95\% & Beta \\
\hline AUS & Low $25 \%$ & 20.5922 & -2.0900 & 0.3025 \\
\hline JPN & Low $25 \%$ & 34.5054 & -2.8732 & 0.0597 \\
\hline
\end{tabular}

\section{CONCLUSIONS}

The growing tendency in ESG development impacts how companies and investors increasingly apply non-financial factors such as ESG Disclosure Score in their analysis process. This study demonstrates that ESG significantly impacts public companies in Australia and Japan regarding accounting and market-based measures. The findings add to the existing literature related to the impact assessment of ESG. Additionally, the paper contributes to the academic research related to the impact of factors in investment decision criteria by displaying a summary of factors influencing firms' returns with and without ESG. The results suggest that the ESG factor significantly affects investment returns and should be considered a variable in the investment process.

This study is divided into two parts: the first related to the significance of ESG and accounting and market-based measures on the returns. The second part, related to the riskreturn performance of ESG portfolios from the same countries, outperforms portfolios that are not ESG based.

We used data panels with the fixed effect regression model methodology, which indicates that ESG is statistically significant for the two countries (Australia and Japan).

For the fixed effect regression model, this study employs the suggestion from different academics such as (Brammer, Brooks, and Pavelin, 2006; Chelawat and Vardhan, 2016) to include accounting and 
market-based factors for corporate financial performance, including how companies perform in sustainability, social and governance. The findings have practical implications for investors and companies. The paper helps in refining that companies that protect the environment are socially responsible and contribute to ethical behavior, business practices, and the long-term viability of the shareholders' wealth.

Comparing our results with other academics, we support Cochran and Wood's (1984) results that suggest that implementing any Environmental, Social, or Governance policies does not impact the short-term returns but the long-term. The ESG implementation reflects control in companies' responsibilities and generates long-term shareholder value. Investors and other stakeholders' pressure to disclose environmental risks, practices, and impact varies among countries (Ambec \& Lanoie, 2007). Our results indicate these differences among the two countries of study: Australia and Japan.

We concur with Pava \& Krausz (1996) that a sector of investors prefers risk management over a high return level. The results show that EDS is statistically significant in companies' stock returns and helps them consider other risk management factors.

The relationship between companies' stock returns and the ESG factor depends on the year observed and the country. Only Australia has a negative relationship between ESG and stock returns. In Australia, the ESG impacts companies' returns for more than one period positively and negatively. Japan only impacts companies' returns when applying ESG the second year after its incorporation, which means that it has to do with the financial market adjustment process. It only was negative significantly in 2007. It must be emphasized that ESG might have a negative relationship in the short run, but it is a value driver in the long term.

To analyze and compare the riskreturn performance of ESG vs. non-ESG portfolios, we constructed 48 different portfolios and used three different criteria. The companies used in the portfolios are the ones that form Australia's S\&P/ASX index and Japan's Nikkei 225 index. The companies included are the ones that provide ESG information from 2010-2019. Each country is analyzed separately.

The criteria for Phase 1 was to compare portfolios of ALL ESG vs. non-ESG disclosures. From the eight portfolios compared, our findings show positive returns for all portfolios; the non-ESG portfolios obtain higher returns and Sharpe ratios than the ESG portfolios.

The criteria for Phase 2 was to compare portfolios of ESG vs. non-ESG using the market capitalization as a filter. From the 32 portfolios compared, we obtain mixed results. Value-weighted non-ESG portfolios outperform ESG portfolios between 12\%-20\% annually for Australia and 2\%-5\% for Japan. The standard deviation for all portfolios is higher than the benchmark. The Japanese portfolios have a very low beta.

The criteria for Phase 3 was to compare only ESG portfolios and value-weigh them based on their ESG disclosure score. The results indicate that the higher returns are obtained from the lowest ESG scores.

Our results concur with (Henriksson et al., 2019). Underweighted lowest ESG scores have higher returns but higher standard deviation and VaR. Our results are contrary to (Lo \& Sheu, 2007), most of our ESG portfolios underperformed the non-ESG.

Australia's portfolios outperformed the benchmark in returns and Sharpe ratio, whereas Japan's did not. All portfolios presented positive alpha; the highest obtained was from Australia's low 25\% market capitalization non-ESG value-weighted portfolio.

In conclusion, ESG investing has gained significant momentum over the last decade. While investors often see ESG as a possible way to reduce investment returns, the integration of companies with environmental, social, and governance policies can be seen as a strategy for risk management and as an exclusionary tool. Thus, contemplating companies with ESG makes investors more informed on their investment; this can be observed with our fixed effect regression 
model's significance and our portfolio's results.

The study clarifies the return-risk relationship on investing in companies with ESG. The financial markets are entering a new ESG investing era. Portfolios created solalely with the condition of ESG provide positive alphas but do not overperform continuously non_ESG portfolio returns. Overall, the empirical evidence supports an association between ESG performance and companies' stock returns. 


\section{REFERENCES}

Alessandrini, F., \& Jondeau, E. (2019). ESG Investing: From sin stocks to smart beta. In Research Paper Series, 19-16.

https://drive.google.com/file/d/1wX1-X8t7K1kSpqzaFT4LvzxDcnYtdTSg/view

Ambec, S., \& Lanoie, P. (2007). When and Why Does it Pay to be Green. Research Gate, 33, 0-40.

Amir, A. Z., \& Serafeim, G. (2018). Why and how investors use ESG information: Evidence from a global survey. Financial Analysts Journal, 74(3), 87-103. https://doi.org/10.2469/faj.v74.n3.2

Atan, R., Alam, M. M., Said, J., \& Zamri, M. (2018). The impacts of environmental, social, and governance factors on firm performance: Panel study of Malaysian companies. Management of Environmental Quality: An International Journal, 29(2), 182-194. https://doi.org/10.1108/MEQ-03-2017-0033

Boffo, R., \& Patalano, R. (2020). ESG Investing: Practices, Progress and Challenges. http://www.oecd.org/finance/ESG-Investing-Practices-Progress-and-Challenges.pdf

Brammer, S., Brooks, C., \& Pavelin, S. (2006). Corporate social performance and stock returns: UK evidence from disaggregate measures. Financial Management, 35(3), 97-116. https://doi.org/10.1111/j.1755-053X.2006.tb00149.x

Calvo, C., Ivorra, C., \& Liern, V. (2014). Finding socially responsible portfolios close to conventional ones. International Review of Financial Analysis, 40, 52-63. https://doi.org/10.1016/j.irfa.2015.03.014

CFA Institute. (2018). Positions on Environmental, Social, and Governance Integration. https://www.cfainstitute.org/-/media/documents/article/position-paper/cfa-institute-positionstatement-esg.ashx

Chelawat, H., \& Trivedi, I. V. (2016). The business value of ESG performance: the Indian context. Asian Journal of Business Ethics, 5(1-2), 195-210. https://doi.org/10.1007/s13520-016-00644

Chow, C. W., \& Wong-Boren, A. (1987). Voluntary Financial Disclosure by Mexican Corporations. The Accounting Review, LXII(3).

Clarke, C., \& Friedman, H. H. (2016). Maximizing Shareholder Value: A theory Run Amok. SSRN Electronic Journal, 1-34. https://ssrn.com/abstract=2796836

Cochran, P. L., \& Wood, R. A. (2014). Corporate Social Responsibility and Financial Performance. The Academy of Management Journal, 27(1), 42-56.

Cuadrado-Ballesteros, B., Garcia-Sanchez, I. M., \& Martinez Ferrero, J. (2016). How are corporate disclosures related to the cost of capital? The fundamental role of information asymmetry. Management Decision, 54(7), 1669-1701. https://doi.org/10.1108/MD-10-2015-0454

Dalal, K. K., \& Thaker, N. (2019). ESG and Corporate Financial Performance: A Panel Study of Indian Companies. The IUP Journal of Corporate Governance, 18(1), 44-60. https://search.proquest.com/docview/2258100521?pq-origsite=gscholar\&fromopenview=true

DVFA, \& EFFAS. (2009). Key Performance Indicators for Environmental, Social and Governance Issues - A Guideline for Corporates on how to Report on ESG and a Benchmark for Investment Professionals on how to integrate ESG into Financial Analysis, 8. https://effas.net/pdf/setter/DVFA criteria for non-financials.pdf

Escrig-Olmedo, E., Fernández-Izquierdo, M. ángeles, Ferrero-Ferrero, I., Rivera-Lirio, J. M., \& Muñoz-Torres, M. J. (2019). Rating the raters: Evaluating how ESG rating agencies integrate $\begin{array}{llll}\text { sustainability } & \text { principles. } & \text { Sustainability } & \text { (Switzerland), }\end{array}$ https://doi.org/10.3390/su11030915

Fabozzi, F. J., Ma, K. C., \& Oliphant, B. J. (2008). Sin stock returns. Journal of Portfolio Management, 35(1), 82-94. https://doi.org/10.3905/JPM.2008.35.1.82

Fink, L. (Blackrock). (2020). Net zero: a fiduciary approach. https://www.blackrock.com/corporate/investor-relations/blackrock-client-letter

Flammer, C. (2015). Does corporate social responsibility lead to superior financial performance? A regression discontinuity approach. Management Science, 61(11), 2549-2568. 
https://doi.org/10.1287/mnsc.2014.2038

Fridson, M. S., \& Alvarez, F. (2011). Financial Statement Analysis: A Practitioner's Guide (4th ed.). John Wiley \& Sons, Ltd.

GSIA. (2019). 2018 Global Sustainable Investment Review. In Global Sustainable Investement Alliance. http://www.gsi-alliance.org/wp-content/uploads/2019/06/GSIR_Review2018F.pdf

Hanck, C., Arnold, M., Gerber, A., \& Schmelzer, M. (2018). Introduction to econometrics with R.

Henriksson, R., Livnat, J., Pfeifer, P., \& Stumpp, M. (2019). Integrating ESG in portfolio construction. Journal of Portfolio Management, 45(4), 67-81. https://doi.org/10.3905/jpm.2019.45.4.067

Ionescu, G. H., Firoiu, D., Pirvu, R., \& Vilag, R. D. (2019). The impact of ESG factors on market value of companies from travel and tourism industry. Technological and Economic Development of Economy, 25(5), 820-849. https://doi.org/10.3846/tede.2019.10294

JSIF. (2020). Sustainable Investment Survey. In Japan Sustainable Investment Forum 2019. Edge International, Inc. http://japansif.com/2019survey-en.pdf

Kaiser, L., \& Schaller, F. (2019). Environmentally (Un-)Friendly Portfolio Construction INVESTMENT CONSULTING. 43 Journal of Investment Consulting, 19(1), 2019.

Le Maux, J., \& Le Saout, E. (2004). The Performance of Sustainability Indexes. Finance India, AprilMay, 737-750. http://dx.doi.org/10.1016/j.jaci.2012.05.050

Liagkouras, K., Metaxiotis, K., \& Tsihrintzis, G. (2020). Incorporating environmental and social considerations into the portfolio optimization process. Annals of Operations Research. https://doi.org/10.1007/s10479-020-03554-3

Lin, K. C., \& Dong, X. (2018). Corporate social responsibility engagement of financially distressed firms and their bankruptcy likelihood. Advances in Accounting, 43(April), 32-45. https://doi.org/10.1016/j.adiac.2018.08.001

Lo, S. F., \& Sheu, H. J. (2007). Is corporate sustainability a value-increasing strategy for business? Corporate Governance: An International Review, 15(2), 345-358. https://doi.org/10.1111/j.1467-8683.2007.00565.x

Malik, A. D., \& Handono, W. A. (2019). Financial Performance Analysis of Soe and Foreign Capital Cement Companies in Indonesia. PEOPLE: International Journal of Social Sciences, 5(1), 267294. https://doi.org/10.20319/pijss.2019.51.267294

MSCI. (2018). MSCI ESG Ratings Methodology - Executive Summary. MSCI ESG Research, 4.

MSCI. (2020). MSCI ESG Metrics Calculation Methodology. December.

Nagy, Z., Cogan, D. G., \& Sinnreich, D. (2013). Optimizing Environmental, Social and Governance Factors in Portfolio Construction: Analysis of Three ESG-Tilted Strategies. SSRN Electronic Journal, 1-23. https://doi.org/10.2139/ssrn.2221524

Nally, D., \& Grygler-Siddons, O. (2014). Technological Breakthroughs. In PwC Global Annual Review. https://doi.org/10.1007/978-1-4899-3496-3_2

Oikonomou, I., Platanakis, E., \& Sutcliffe, C. (2018). Socially responsible investment portfolios: Does the optimization process matter? British Accounting Review, 50(4), 379-401. https://doi.org/10.1016/j.bar.2017.10.003

Patel, S. A., \& Dallas, G. S. (2005). Transparency and Disclosure: Overview of Methodology and Study Results - United States. SSRN Electronic Journal. https://doi.org/10.2139/ssrn.422800

Pava, M. L., \& Krausz, J. (1996). The association between corporate social-responsibility and financial performance: The paradox of social cost. Journal of Business Ethics, 15(3), 321-357. https://doi.org/10.1007/BF00382958

Pedersen, L. H., Fitzgibbons, S., \& Pomorski, L. (2020). Responsible Investing : The ESG-Efficient Frontier. SSRN Electronic Journal, March, 1-49. https://ssrn.com/abstract=346641

Razmpa, S., \& Kosowski, R. (2020). ESG Integration within minimum variance portfolios (Issue April).

Revelli, C., \& Viviani, J.-L. (2015). Financial performance of socially responsible investing (SRI): What have we learned? A meta-analysis. Business Ethics, 24(2), 158-185. 
https://doi.org/10.1111/beer.12076

RIAA Annual Report 2020 Financial Year. (2020). https://responsibleinvestment.org/wpcontent/uploads/2020/12/RIAA_Annual-Report-FY20-1.pdf

Scholz, H., \& Wilkens, M. (2005). Investor specific performance measurement: a justification of sharpe ratio and treynor ratio. International Journal of Finance, 17(4), 3671-3691.

Serafeim, G., \& Grewal, J. (2019). ESG Metrics: Reshaping Capitalism? Harvard Business School Technical Note 116-037.

Standard and Poor's. (2004). Standard \& Poor's Corporate Governance Scores and Evaluations Criteria, Methology and Definitions. McGraw-Hill Companies Inc., New York, 1-23.

Starks, L. T., Venkat, P., \& Zhu, Q. (2017). Corporate ESG Profiles and Investor Horizons. SSRN Electronic Journal. https://doi.org/10.2139/ssrn.3049943

Sullivan, E. J. (2006). A brief history of the capital asset pricing model. APUBEF Proceedings - Fall, 207-210. https://pdfs.semanticscholar.org/6959/9b6e39197761b95ebd4c2e92c4c25d1f9d31.pdf

Tai, P. H., \& Kuo, T. (2010). Research notes Chiang Kai-Shek revisited. American Journal of Chinese Studies, 17(1), 81-86. https://www.jstor.org/stable/44288010

Ullmann, A. A. (1985). Data in Search of a Theory: A Critical Examination of the Relationships Among Social Performance, Social Disclosure, and Economic Performance of U.S. Firms. Academy of Management Review, 10(3), 540-557. https://doi.org/10.5465/amr.1985.4278989

UN Global Compact, Federal Department of Foreign Affairs Switzerland, \& Corporation, I. F. (2005). Who cares wins: Investing for Long-Term Value Creation. Integrating Environmental, Social and Governance Value Drivers in Asset Management and Financial Research, 1-25.

UN PRI. (2017). A Blueprint for Responsible Investment (pp. 1-34). www.blueprint.unpri.org@PRI_News-\#PRIBlueprint

Wright, J. H., Wong, W.-K., Khan, H., Du, J., Wirolr, R. U., Vvhw, D. Q. G., Wiederhold, G., Wheatley, M., Kellner-Rogers, M., Wendee, P. M., van Suntum, U., Kaptan, M., Ilgmann, C., Users, I. T. O., Tu, J., Zhou, G., Thorbecke, W., Thomas, I., Taamouti, A., ... Hasund, K. P. (2010). Many risks, one (optimal) portfolio. SSRN Electronic Journal, 41(2), 1-20. https://doi.org/10.16953/deusbed.74839 